\title{
FMADM: YAGER MODEL IN FUZZY DECISION MAKING
}

\author{
KISWORO \\ Department of Information System, \\ Universitas Teknokrat Indonesia, Indonesia \\ e-mail: kisworo@teknokrat.ac.id
}

\begin{abstract}
This paper presents Yager model, i.e. standard form of Fuzzy Multi-Atributte Decision Making (FMADM) in fuzzy decision environment. Simulasion of this model would be performed under scope of fuzzy decisionmaking process to show its existence. As academics, researchers, and practitioners know on it, besides the FMADM, so is there Fuzzy Multi-Objective Decision Making (FMODM) at where the both has their same derivation, e.i. Fuzzy Multi-Criteria Decision Making (FMCDM). Related to the matter, significant value that could be represented then gives contribution to team work-oriented principal of decision makers.
\end{abstract}

Keywords: Yager Model, FMADM, FMODM, FMCDM, fuzzy decision-making.

\section{Background}

Fuzzy sets ( (Zadeh, 1965), (Bellman, 1970), (Ekel, 2002), (Zimmermann H. -J., 2001), (Zimmermann, Fuzzy Set Theory, 2010), (Chen, 2001), (Muzimoto, 1981), (Hohle, 1996), (Bojadziev, 2007)) established by the father of fuzzy sets and fuzzy logic Lotfi A. Zadeh ( (Seising, 2006), (Gupta, 2010), 2017), (Zadeh L. , __ a), (Zadeh L. , Principal Achievements: A Personal Statement (1965-1914), b), (Zadeh L. , Fuzzy Logic-Forty Years Later: A Personal Perspective, 2015), (Zadeh L. , The Birth and Evolution of Fuzzy Logic, 1990)) is very affected to Multi-Criteria Decision Making (MCDM). So, MCDM that is initially in crisp then given fuzzy characteristics under the name Fuzzy Multi-Criteria Decision Making (FMCDM) (Abdullah, 2013), proposed by C. Carlsson and R. Fuller in 1996 (Carlsson, 1996: 133). As a consequence, its two main banches, e.i. Multi-Attribute Decision Making (MADM) dan Multi-Objective Decision Making (MODM), then are under the name Fuzzy Multi-Attribute Decision Making (FMADM) and Fuzzy Multi-Objective Decision Making (FMODM) ( (Kahraman, 2008), (Kahraman C. O., 2015), (Mardani, 2015), (Kusumadewi, 2006: ch. 4-5)) respectively. In scheme:

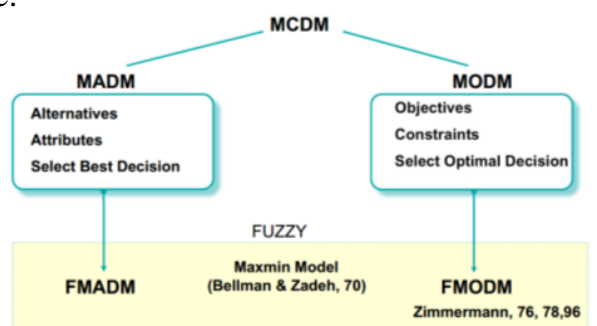

Figure1 FMADM in FMCDM (Ribeiro, 2010)
Next to fuzzy sets, so is fuzzy logic ( (Gupta, 2010), (Zadeh L. , ___ a), (Zadeh L. , Principal Achievements: A Personal Statement (1965-1914), b), (Zadeh L. , Fuzzy Logic-Forty Years Later: A Personal Perspective, 2015), (Zadeh L. , The Birth and Evolution of Fuzzy Logic, 1990)) which (Bojadziev, 2007) said that the both via fuzzy numbers has fuzzy relations within problem solving. Furtherly, it was addressed for proving "Fuzzy sets and fuzzy relations play an important role in fuzzy logic" (Bojadziev, 2007, p. 1). Related to fuzzy logic, it was said: "Fuzzy logic is an extension of the many-valued logic in the sense of incorporating fuzzy sets and fuzzy relations as tools into the system of many-valued logic. Fuzzy logic provides a methodology for dealing with linguistic variables and describing modifiers like very, fairly, not, etc. Fuzzy logic facilitates common sense reasoning with imprecise and vague propositions dealing with natural language and serves as a basis for decision analysis and control actions" (Bojadziev, 2007, p. 37).

The meant both, e.i. fuzzy sets and fuzzy logic, support so much what so called fuzzy decision-making process ( (Zimmermann H. -J., 2001), (Abdullah, 2013), (Bojadziev, 2007). Inside, Yager model presents to aggregating preference information and ranking given alternatives through a method called as ordered weighted averaging operator ( (Kusumadewi, 2006: ch. 4-5), (Cagman, 2011), (Yager, 1988), (Yager R. R., 1997), (Yager R. R., The Ordered Weighted Averaging Operators, 1997), (Yager R. R., Extending Multicriteria Decision Making by Mixing t-norms and OWA Operators, __ )). It ranges Group Support System (GSS) by means of improving Group Decision Making (GDM) quality. In certain literatures, its scope is Fuzzy Multi-Expert Multi-Attribute Decision Making (MEFMADM). This paper focuses on FMADM in specification Yager model as background of MEFMADM existence because before the model becomes standard of FMADM. So, MADM suits its characteristics, that then is strengthened by fuzzy as FMADM should go through two steps: rating and ranking. As a consequence, this paper via the restrictions would prove Yager model within simulasion under its procedure.

Why focuses on FMADM: Yager model? First: the reason of standard status had by Yager model in FMADM. Second: extensive ranges had by Yager model till GSS-GDM under scope of MEF-MADM. Contribution: team work-oriented decision makers. Nuala Beck in 1995 at p. 125 (Bojadziev, 2007) suggested: "the skills that all of us need to get ahead in this challenging times ... the ability to work as part of a 
team, ... the ability to communicate, ... the ability to use a computer, ... the ability to do basic math."

\section{Yager Model}

Yager model (Kusumadewi, 2006: ch. 4-5) is as below:

a. Determain interrelated attributes in form of pairwise comparison, M, based on Saaty's hierarchycal procedure ( (Saaty, 2008), (Saaty, How to Make A Decision: The Analytic Hierarchy Process, 1990), (Saaty, The Analytic Hierarchy Process, 1980), (Triantaphyllou, 1995), (Kousalya, 2012)):

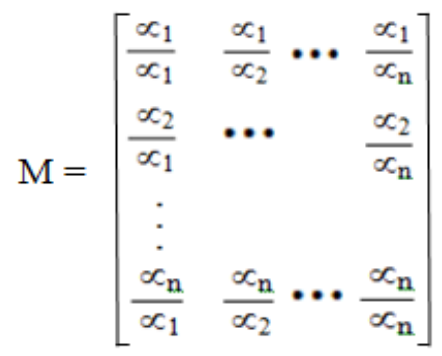

with $\frac{\propto_{i}}{\propto_{j}} \quad$ as relative interest of attribute $a_{i}$ against attribute $a_{j}$. Here is the absolute numbers of fundamental scale founded by Saaty ((Saaty, Decision Making with the Analytic Hierarchy Process, 2008) p. 86, (Saaty, How to Make A Decision: The Analytic Hierarchy Process, 1990) p. 32, (Triantaphyllou, 1995) p. 3, (Kousalya, 2012) p. 864).

\begin{tabular}{|c|c|c|}
\hline $\begin{array}{l}\begin{array}{l}\text { Intensity of } \\
\text { Importance }\end{array} \\
\text { Int }\end{array}$ & Definition & Explanation \\
\hline 1 & Equal Importance & Two activities contribute equally to the objective \\
\hline 2 & & \\
\hline 3 & Moderate importance & $\begin{array}{l}\text { Experience and judgement slightly favour } \\
\text { one activity over another }\end{array}$ \\
\hline 4 & Moderate plus & \\
\hline 5 & Strong importance & $\begin{array}{l}\text { Experience and judgement strongly favour } \\
\text { one activity over another }\end{array}$ \\
\hline 6 & Strong plus & \\
\hline 7 & $\begin{array}{l}\text { Very strong or } \\
\text { demostrated importance }\end{array}$ & $\begin{array}{l}\text { An activity is favoured very strongly over } \\
\text { another, its dominance demonstrated in practice }\end{array}$ \\
\hline 8 & Very, very strong & \\
\hline & Extreme importance & $\begin{array}{l}\text { The evidence favouring one activity over another } \\
\text { is of the highest possible order of affirmation }\end{array}$ \\
\hline $\begin{array}{l}\text { Reciprocals } \\
\text { of above }\end{array}$ & $\begin{array}{l}\text { If activity } i \text { has one of the } \\
\text { above non-zero numbers } \\
\text { assigned to it when } \\
\text { compared with activity } j \text {. } \\
\text { then } j \text { has the reciprocal } \\
\text { value when compared } \\
\text { with } i\end{array}$ & A reasonable assumption \\
\hline $1.1-1.9$ & $\begin{array}{l}\text { If the activities are very } \\
\text { close }\end{array}$ & $\begin{array}{l}\text { May be difficult to assign the best value but } \\
\text { when compared with ohter contrasting activities } \\
\text { the size of the small numbers would not be too } \\
\text { noticicable, yet they can still indicate the } \\
\text { relative importance of the activities. }\end{array}$ \\
\hline
\end{tabular}

b. determain weight $\mathrm{w}_{\mathrm{j}}$ that is consistent to every single attribute based on Saaty's eigenvector method. (If needed, then it could be examined by Consistency Ratio (CR). Here, it is used).

c. account value:

$$
\left(\widetilde{\mathrm{C}}_{\mathrm{j}}\left(\mathrm{X}_{\mathrm{i}}\right)\right)^{\mathrm{w}_{\mathrm{j}}}
$$

d. determain interaction of all $\left(\widetilde{\mathrm{C}}_{\mathrm{j}}\left(\mathrm{X}_{\mathrm{i}}\right){ }^{\mathrm{w}_{\mathrm{j}}}\right.$, as:

$$
\widetilde{D}=\left\{\left(X_{i}, \min \left(\mu C_{j}\left(X_{i}\right)\right)^{w_{j}}\right)|| i=1, \ldots, n ; j=1, \ldots, m\right\}
$$

e. choose $X_{i}$ under the biggest membership functions in $\widetilde{\mathrm{D}}$, established as optimal alternative.

\section{Case: Selecting Variables Via Modeling}

For simulating the case, the variables measured are the following:

a. Given alternatives: A1, A2. A3.

b. Given criterions: $\mathrm{C} 1, \mathrm{C} 2, \mathrm{C} 3$.

\section{Table 1 Criteria}

\begin{tabular}{|c|l|}
\hline Criteria & \multicolumn{1}{|c|}{ Descriptions } \\
\hline C1 & Criteria 1 \\
\hline C2 & Criteria 2 \\
\hline C3 & Criteria 3 \\
\hline
\end{tabular}

c. Membership functions of every alternative

\begin{tabular}{|c|c|c|c|}
\hline $\begin{array}{c}\text { Range of } \\
\text { Values }\end{array}$ & Initials & Fuzzy Numbers & Values \\
\hline $\begin{array}{c}\mathrm{a}<=\mathrm{C} 1 \\
<=\mathrm{b}\end{array}$ & I & Inportant & N2 \\
\hline $\begin{array}{c}\mathrm{b}<\mathrm{C} 1 \\
<=\mathrm{c}\end{array}$ & IE & Inportant Enough & N1 \\
\hline $\begin{array}{c}c<\mathrm{C} 1 \\
<=\mathrm{d}\end{array}$ & NI & Not Important & No \\
\hline \multicolumn{4}{|c|}{$\begin{array}{l}\text { Descriptions for Range of Values and Values: } \\
\text { 1. Values a to d: ascending. } \\
\text { a = threshold for the highest value. } \\
\mathrm{d}=\text { threshold for the lowest value. } \\
\text { a to d get values are determained in integer type from } \\
\text { the lowest value. } \\
\text { 2. Values } \mathrm{N} \text { : discending. } \\
\mathrm{N} 2=\text { the highest value. } \\
\mathrm{N} 0=\text { the lowest value. } \\
\mathrm{N} 2 \text { to } \mathrm{N} 0 \text { get values are determained in decimal type } \\
\text { in range between } 1 \text { and } 0 .\end{array}$} \\
\hline
\end{tabular}
available at every existed criteria/attribute:

Table 2 Criteria1 in range of values a to d

\begin{tabular}{|c|c|c|c|}
\hline $\begin{array}{c}\text { Range of } \\
\text { Values }\end{array}$ & Initials & Fuzzy Numbers & Values \\
\hline $\mathrm{C} 2=\mathrm{e}$ & $\mathrm{I}$ & Inportant & No \\
\hline $\mathrm{C} 2=\mathrm{f}$ & IE & Inportant Enough & N1 \\
\hline $\mathrm{C} 2=\mathrm{g}$ & $\mathrm{NI}$ & Not Important & $\mathrm{N} 2$ \\
\hline \multicolumn{4}{|c|}{$\begin{array}{l}\text { 1. Values a to d: descending. } \\
\mathrm{e}=\text { threshold for the lowest value. } \\
\mathrm{g}=\text { threshold for the highest value. } \\
\mathrm{e} \text { to g get values are determained in integer type from } \\
\text { the lowest value. }\end{array}$} \\
\hline $\begin{array}{l}\text { 2. Value } \\
\mathrm{N} 2= \\
\mathrm{N} 0= \\
\mathrm{N} 2 \text { to } \\
\text { in ran }\end{array}$ & $\begin{array}{l}\mathrm{N} \text { : ascenc } \\
\text { e highest } \\
\text { e lowest } \\
\text { J0 get val }\end{array}$ & $\begin{array}{l}\text { ng. } \\
\text { alue. } \\
\text { lue. } \\
\text { es are determained } \\
1 \text { and } 0 .\end{array}$ & al type \\
\hline
\end{tabular}

Table 3 Criteria1 in range of values e to $\mathrm{g} e$ 
Table 4 Criteria1 in range of values $h$ to $\mathrm{g} \mathrm{k}$

\begin{tabular}{|c|c|c|c|}
\hline $\begin{array}{c}\text { Range of } \\
\text { Values }\end{array}$ & Initials & Fuzzy Numbers & $\begin{array}{l}\text { Value } \\
\mathbf{s}\end{array}$ \\
\hline $\mathrm{h}<=\mathrm{C} 3<=\mathrm{i}$ & NI & Not Important & $\mathrm{N} 2$ \\
\hline $\mathrm{i}<\mathrm{C} 3<=\mathrm{j}$ & $\mathrm{IE}$ & Important Enough & N1 \\
\hline $\mathrm{j}<\mathrm{C} 3<=\mathrm{k}$ & I & Important & N0 \\
\hline \multicolumn{4}{|c|}{$\begin{array}{l}\text { Descriptions for Range of Values and Values: } \\
\text { 1. Values } \mathrm{h} \text { to k: ascending. } \\
\mathrm{h}=\text { threshold for the highest value. } \\
\mathrm{k}=\text { threshold for the lowest value. } \\
\mathrm{h} \text { to } \mathrm{k} \text { get values are determained in integer type from } \\
\text { the lowest value. } \\
\text { 2. Values } \mathrm{N} \text { : discending. } \\
\mathrm{N} 2=\text { the highest value. } \\
\mathrm{N} 0=\text { the lowest value. } \\
\mathrm{N} 2 \text { to } \mathrm{N} 0 \text { get values are determained in decimal type in } \\
\text { range between } 1 \text { and } 0 \text {. }\end{array}$} \\
\hline
\end{tabular}

\section{Yager Model Via Case Simulation}

As with Yager model (sub 2), simulation of the case (sub 3) as the below:

\begin{tabular}{|c|c|c|c|}
\hline \multicolumn{4}{|c|}{ a. Determine Pairwise Comparisons Matrix } \\
\hline & C1 & C2 & C3 \\
\hline C1 & 1,0000 & 5,0000 & 0,4286 \\
\hline C2 & 0,2000 & 1,0000 & 0,2000 \\
\hline C3 & 2,3333 & 5,0000 & 1,0000 \\
\hline \multicolumn{4}{|c|}{ 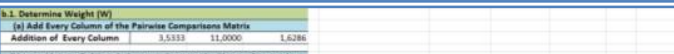 } \\
\hline 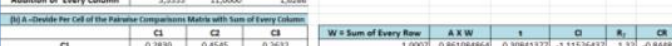 & wemedtimente- & Axw & 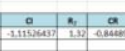 \\
\hline \multicolumn{4}{|c|}{ 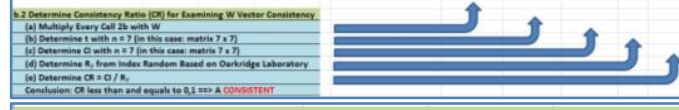 } \\
\hline \multicolumn{4}{|c|}{ c. Determine $\mathrm{C}=$ Membership Function Powered by W } \\
\hline \multicolumn{4}{|c|}{ (a) Membership Function of Every Alternative } \\
\hline \multirow{2}{*}{ Alternatif } & \multicolumn{3}{|c|}{ Criteria } \\
\hline & C1 & C2 & C3 \\
\hline $\mathbf{x} 1$ & 0,3000 & 0,5000 & 0,1000 \\
\hline$\times 2$ & 0,8000 & 0,2000 & 0,4000 \\
\hline $\mathbf{x} 3$ & 0,3000 & 0,7000 & 0,8000 \\
\hline \multicolumn{4}{|l|}{ (a) Results: Values C } \\
\hline \multirow{2}{*}{ Alternatif } & \multicolumn{3}{|c|}{ Criteria } \\
\hline & C1 & C2 & C3 \\
\hline $\mathrm{x} 1$ & 0,2997 & 0,4997 & 0,0998 \\
\hline $\mathbf{x 2}$ & 0,9415 & 0,6472 & 0,7806 \\
\hline $\mathbf{x} 3$ & 0,1247 & 0,5397 & 0,6799 \\
\hline \multicolumn{4}{|l|}{ d. Determine D with Min } \\
\hline Alternatif & D & & \\
\hline $\mathrm{x} 1$ & 0,0998 & & \\
\hline $\mathbf{x} 2$ & 0,6472 & & \\
\hline x3 & 0,1247 & & \\
\hline \multicolumn{4}{|c|}{ e. Decision Alternatives as Base for Decision Making } \\
\hline Alternatif & D & Ranking & \\
\hline $\mathrm{x} 1$ & 0,0998 & III & \\
\hline $\mathrm{x} 2$ & 0,6472 & 1 & \\
\hline x3 & 0,1247 & II & \\
\hline
\end{tabular}

\section{Conclusion}

Yager model is capable to bear decision alternatives. It works under its procedure. Ordered weighted averaging is useful all over process from the begining to the end. Fuzzy gives characteristic according to the given variables. FMADM via Yager model presents in form of ranking. For development, under MEF-MADM, GSS is ranged to increase quality of GDM, i.e. especially in scope of team work-oriented principal of decision makers.

\section{References}

. (2017). Lotfi Zadeh has passed away. USA, California: Berkeley|EECS: Electrical Engineering and Computer Sciences. News. Available online at https://eecs.berkeley.edu/news.

Abdullah, L. (2013). Fuzzy Multi Criteria Decision Making and Its Applications: A Brief Review of Category. The 9th International Conference on Cognitive Science. (C) 2013 The Authors: Elsevier Ltd. Open access under CC BY-NCND license. Selection and/or peer-review under responsibility of the Universiti Malaysia Sarawak. doi: 10.1016/j.sbspro.2013.10.213.

Bellman, R. E. (1970). Decision making in a fuzzy. Management Science, 17, B141-B164.

Bojadziev, G. \&. (2007). Advances in Fuzzy Systems Applications and Theory - Vol. 2: Fuzzy Logic for Business, Finance, and Management. Singapore: World Scientific Publishing Co. Pte. Ltd.

Cagman, N. \&. (2011). A New Group Decision-Making Method Based on Fuzzy Set Operation. European Journal of Pure and Applied Mathematics Vol. 4, No. 1, 42-49.

Carlsson, C. \&. (1996: 133). Fuzzy multiple criteria decision making: Recent developments. Fuzzy Sets and Systems, 78, 139- 153.

Chen, G. \&. (2001). Introduction to Fuzzy Sets, Fuzzy Logic, and Fuzzy Control Systems. Florida: CRC Press LLC.

Ekel, P. Y. (2002). Fuzzy Sets and Models of Decision Making. Computers and Mathematics with Applications, 44, 863-875.

Gupta, M. M. (2010). Forty-Five Years of Fuzzy Sets and Fuzzy Logic-A Tribute Professor Lofty A. Zadeh (The Father of Fuzzy Logic). 1026-3098 (C) 2011 Sharif University of Technology: Production and hosting by Elsevier B.V. www.sciencedirect.com.

Hohle, U. (1996). On the Fundamentals of Fuzzy Set Theory. Journal of Mathematical Analysis and Applications, 201, 786-826.

Kahraman, C. (. (2008). Fuzzy Multi-Criteria Decision

Making: Theory and Applications with Recent Developments. USA, New York: Springer Science + Business Media, LLC.

Kahraman, C. O. (2015). Fuzzy Multicriteria DecisionMaking: A Literature Review. International Journal of Computational Intelligence Systems, Vol. 8, No. 4, 637-666.

Kousalya, P. R. (2012). Analytical Hierarchy Process Approach - in Application of Engineering Education. Mathematica Aeterna, Vol. 2, No.10, 861-878.

Kusumadewi, S. H. (2006: ch. 4-5). Fuzzy MultiAttribute Decision Making. Indonesia, Yogyakarta: Graha Ilmu. 
Mardani, A. J. (2015). Fuzzy Multiple Criteria DecisionMaking Techniques and Applications-Two decades review from 1994 to 2014. Expert Systems with Applications. https://www.researchgate.net/publication/2722 39956.

Muzimoto, M. (1981). Fuzzy Sets and Their Operations. Information and Control, 48, 30-48.

Ribeiro, R. A. (2010). Fuzzy Decision Making. Slide: CA3/CTS/UNINOVA. www.uninova.pt/ca3/.

Saaty, T. L. (1980). The Analytic Hierarchy Process. USA, New York: McGraw-Hill.

Saaty, T. L. (1990). How to Make A Decision: The Analytic Hierarchy Process. International Journal of Operation Research, 48, 9-26: Upload by Saaty, T. L. at https://www.researchgate.net, 02-02-2015.

Saaty, T. L. (2008). Decision Making with the Analytic Hierarchy Process. Int. J. Services Science, Vol. 1, No. 1: Uploaded by Saaty, T. L. at https://www.researchgate.net, 31-12-2014.

Seising, R. (2006). Proposals for Future Developments in Fuzzy Sets Technology. 2006 IEEE International Conference on Fuzzy Systems: Sheraton Vancouver Wall Centre Hotel, Vancouver, BC, Canada 16-21 July, 2006.

Triantaphyllou, E. \&. (1995). Using the Analytic Hierarchy Process for Decision Making in Engineering Applications: Some Challenges. Inter'l Journal of Industrial Engineering: Applications and Practice, Vol. 2, No.1, pp. 3544.

Yager, R. R. ). Extending Multicriteria Decision Making by Mixing t-norms and OWA Operators. International Journal Intelligent Systems, 20, 453-474.

Yager, R. R. (1988). On Ordered Weighted Averaging Aggregation Operators in Multicriteria Decision Making. IEEE Trans. Syst. Man Cyber, 18,183-190.

Yager, R. R. (1997). The Ordered Weighted Averaging Operators. Theory and Applications. USA, Boston: Kluwer.

Yager, R. R. (1997). The Ordered Weighted Averaging Operators. Theory and Applications. USA, Boston: Kluwer.

Zadeh, L. ( a). Publication List: Principal Papers Are Highlighted. https://people.eecs.berkeley.edu/ zadeh/papers/ index.htm.

Zadeh, L. b). Principal Achievements: A

Personal Statement (1965-1914). https://people.eecs.berkeley.edu/ zadeh/suprco. html.

Zadeh, L. (1965). Fuzzy Sets. Information and Control, 8, 338-353.

Zadeh, L. (1990). The Birth and Evolution of Fuzzy Logic. UK, The Birth and Evolution of Fuzzy Logic: International Journal General Systems, Vol. 17, 95-105. en.bookfi.net.
Zadeh, L. (2015). Fuzzy Logic-Forty Years Later: A Personal Perspective. USA, Univercity of Calofornia: Computer Science Devision, Department of EECS (USA). http://fuzzieee2011.nutn.edu.tw/download/Fuzz yLogic-FortyYearsLater-LotfiZadeh.pdf.

Zimmermann, H. -J. (2001). Fuzzy Set Theory and Its Applications, Fourth Edition. USA, New York: Springer Science+Business Media.

Zimmermann, H. -J. (2010). Fuzzy Set Theory. Aachen: John Wiley \& Sons, Inc (Germany): WIREs Comp Stat, 2, 317-332. 